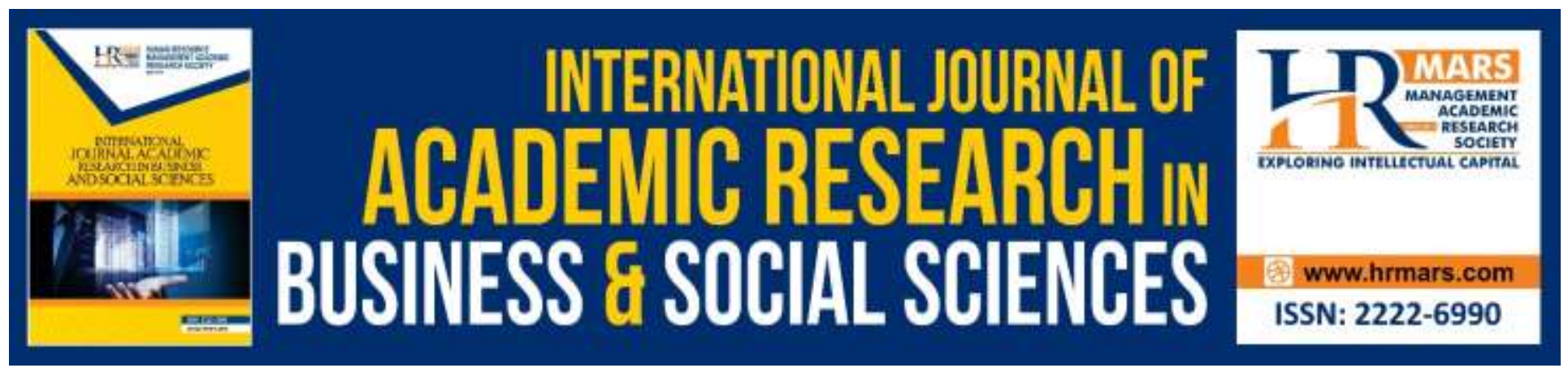

\title{
Pros and Cons of Deputy Regional Head Role Position in Indonesia
}

\section{Mukarto Siswoyo}

To Link this Article: http://dx.doi.org/10.6007/IJARBSS/v10-i2/6925

DOI:10.6007/IJARBSS/v10-i2/6925

Received: 04 January 2020, Revised: 27 January 2020, Accepted: 01 February 2020

Published Online: 18 February 2020

In-Text Citation: (Siswoyo, 20220)

To Cite this Article: Siswoyo, M. (20220). Pros and Cons of Deputy Regional Head Role Position in Indonesia. International Journal of Academic Research in Business and Social Sciences, 10(2), 245-254.

Copyright: (C) 2020 The Author(s)

Published by Human Resource Management Academic Research Society (www.hrmars.com)

This article is published under the Creative Commons Attribution (CC BY 4.0) license. Anyone may reproduce, distribute, translate and create derivative works of this article (for both commercial and non-commercial purposes), subject to full attribution to the original publication and authors. The full terms of this license may be seen

at: http://creativecommons.org/licences/by/4.0/legalcode

Vol. 10, No. 2, 2020, Pg. 245 - 254

http://hrmars.com/index.php/pages/detail/IJARBSS

JOURNAL HOMEPAGE

Full Terms \& Conditions of access and use can be found at http://hrmars.com/index.php/pages/detail/publication-ethics 


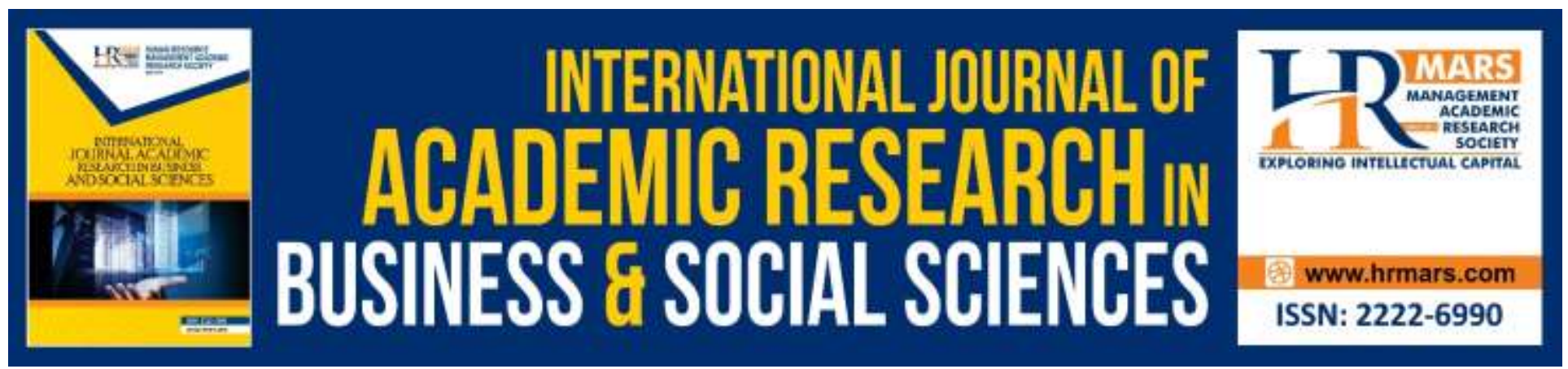

\title{
Pros and Cons of Deputy Regional Head Role Position in Indonesia
}

\author{
Mukarto Siswoyo \\ Department of Public Administration, Faculty of Politic and Social Sciences, Universitas Swadaya \\ Gunung Jati, Cirebon, Indonesia \\ Email: mukartosiswoyougj@gmail.com
}

\begin{abstract}
The position of deputy regional head in Indonesia has reaped many pros and cons. The deputy region head ease the regional head's duties and anticipate a leadership vacuum if the regional head is serving detention period or being temporarily unavailable. On the other hand, deputy regional head has many conflicts with the regional head. This conflict can disrupt the operation of the regional government, so that the existence of the deputy regional head has more harm than benefits. The necessity of deputy regional head in Indonesia needs to take into consideration by the area, population, complexity of regional government affairs, and the effectiveness of regional government operations. However, these considerations are often defeated by the political interests of political parties by placing their cadres as deputy regional heads.
\end{abstract}

Keywords: Deputy Regional Head, Regional Government, Conflict of Regional Head and Deputy Regional Head

\section{Introduction}

According to 1945 Constitution of the Republic of Indonesia (UUD 1945) in article 18 paragraph (1), it confirms that the Republic of Indonesia is divided into provincial regions. Then, the provincial regions are divided into regencies and cities, each of province, regency, and city has a regional government, which is regulated by law. In paragraph (2), it is emphasized that the provincial, regency, and city regional governments regulate and manage their own government operations according to the principle of autonomy and assistance tasks. Furthermore, paragraph (3) emphasizes that the Governors, Regents and Mayors as respective heads of provincial, district and city regional governments shall be democratically elected.

The 1945 Constitution only stipulates Governor, Regent, and Mayor as regional head, and does not recognize deputy regional head position. The position of deputy region head is contained in Law Number 22 of 1999 which later amended by Law Number 32 of 2004 and finally amended by Law Number 23 of 2014 concerning Regional Government. In Article 63 of Law Number 23 of 2014, it is 
stated that the deputy head province is called deputy governor, meanwhile the deputy district head is called the deputy regent, and the deputy city head is called the deputy mayor (Indonesia, 2014).

In further, the position of deputy regional head reaped many pros and cons. The deputy regional head can assist the regional head's tasks in carrying out regional government and can replace the regional head if the regional head is serving a period of detention or being temporarily unavailable. On the other hand, many regional heads were involved in conflicts with their representatives. It made the partnership broke out so that the existence of the deputy regional head actually disrupted the regional government operation. Data from the Ministry of Home Affairs (Wahid, 2018) shows that during the 2004-2015 regional elections there were 971 (94\%) regional heads who broke their partnership with their representatives and only 77 (6\%) regional heads who did not.

Many conflicts of regional heads with their representatives and split their partnership raises several the questions, which also becomes the objectives of this study:

- What is the positive and negative side of the deputy regional head existence in Indonesia?

- What are factors made the regional head conflict and break the partnership with his representative?

- Is the position of deputy regional head in Indonesia needed?

\section{Literature Review}

The concept of democracy is practiced throughout the world differently from one country to another. Democracy has become a paradigm in the world communication language about government systems and political systems that are considered ideal (Asshiddiqie, 2010). There are two groups that are very important in democracy, namely: constitutional democracy group and democratic group that base themselves on communism. The fundamental differences between the two groups is that constitutional democracy aspires to a government whose power is limited, namely a state (rechtsstaat) which is subject to the rule of law. On the contrary, the democracy which bases itself on communism aspires that the government of its power is unlimited (machtsstaat) and also totalitarian (Huda, 2012).

One basic requirement to implement a democratic government under the rule of law is a free general election (Budiardjo, 2008. The characteristic of a democratic political system lays in the democratic order which forms the ruler, so that elements of democracy not only become norms of the state, but also empirically work in accordance with the corridors of democracy (Sugiyanto, 2018). In democracy, the idea of participation is also put forward by Diamond, Linz, andLipzet, who explained that there is political participation that involved as many people as possible in regular and fair elections, and no group was excluded in the criteria of democracy. There are civil and political freedoms in democracy, namely freedom of speech, freedom of the press, freedom of association, and organization to compete and participate in politics (Rais, 1995). In addition, democracy is based on a number of values including leadership change regularly. In a democracy, leadership change based on descent, self-election or coup d'etat is considered unnatural (Budiardjo, 2008).

One of democratization steps carried out in the Indonesia reform era was the general election to directly elect regional heads (pilkada) which is regulated in Law Number 32 of 2004 concerning Regional Government. This law requires all regional heads in Indonesia to be elected through the elections starting in mid 2005. The implementation of this direct election has covered the shortcomings that existed in the previous law, as an implementation of the amendment to the 
Constitution of the Republic of Indonesia which has changed the system of state government administration (Hutapea, 2015). Since then, all regional heads whose term of office has expired must be elected through the elections. The election aims to make local governments more democratic by giving people the right to determine the regional head (simamora, 2011). It is different from the previous regional head election which was indirect because chosen by the DPRD (Budiardjo, 2008; Hanafi, 2016).

The direct election of regional heads is one of the manifestations of democratic instruments in order to create a more democratic government. With this system, the hope of the realization of people's sovereignity in the government system is believed to be realized as a whole, considering that the democracy system is a direct order mandated by the 1945 Constitution (Simamora, 2011). In Indonesia, regional heads are elected in a package with deputy regional heads (Sinaga, 2018). However, the deputy head of the region is not explicitly mentioned as part of the regional government. In other words, the existence of deputy regional heads based on these laws and regulations can still be said to be abstract (Prihatiningtyas, 2018). The position of deputy regional head for the regency/city government level has only been in existence since the enactment of Law Number 22 of 1999 concerning the Regional Government. For the provincial government, the position of deputy governor had indeed already existed. The position of deputy governor was previously directly appointed by the governor. Along with the era of regional autonomy, the position of deputy head of the region-both the level of regency/city government and provincial government-is chosen as a partner with the regional head by the DPRD. Based on Law Number 32 of 2004, regional head and deputy regional head are elected jointly and directly by the people (Haruni, 2015).

By using a comparative approach, the actual existence of the deputy regional head is not only recognized in Indonesia but also in Spain, United States, Australia, and Canada. The deputy regional head is called the lieutenant governor, which is as same meaning as the vice governor. In Australia, lieutenant governors assigned as administrators or acting governors. In some states, the deputy regional or state head is called deputy governor or lieutenant governors. It functions as a candidate to be elected in the next election and ready to take the governor position. The election of lieutenant governors varies from country to country. There are somestate who elect the governor and his representatives in a package and the otherelect separately or individually and others choose both at the same time (Asshiddiqie, 2010).

The position of deputy head of the region must be truly filled by people who have knowledge of government, law, and influence in the bureaucratic organization, since the deputy headof the region is given duties and authorities for matters that are directly related to government functions. There are lines that connect between a neutral and professional bureaucracy with political office that is attached to the head of the region and the DPRD. The deputy head of the region can replace the regional head if he/she is unable to be present or resign. The deputy head of the region is very possibly and expected to be a figure that is capable of accommodating and overcoming problems that exists in the implementation of government, thus the position of deputy head of the region must exist (Baswir, 1999).

Regional government management will be more effective if the implementation of the division of authority between the regional head and his deputy is based on laws and regulations, and also is written down (formal juridical). The division of tasks, functions, and authority is carried out at initial 
INTERNATIONAL JOURNAL OF ACADEMIC RESEARCH IN BUSINESS AND SOCIAL SCIENCES Vol. 10, No. 2, Feb, 2020, E-ISSN: 2222-6990 ¿ 2020 HRMARS

stages (planning) of the implementation of regional government. Therefore, the implementation which refers to clear rules will be able to increase the effectiveness of the administration of the regional government (Solihat \& Nugraha, 2017).

\section{Research Method}

This study was conducted using qualitative method. Qualitative study is a method for exploring and understanding the meaning which - by a number of individuals or groups of people - is ascribed to social or humanitarian problems (Creswell, 2014).The data in this study were obtained from literature and documentation. Data analysis is performed through data reduction, data display, verification, and conclusion drawing.

\section{Results and Discussion}

The regional government in Indonesia is led by the regional head, namely the governor for the province, the regent for the regency, and the mayor for the city area. According to Law Number 23 of 2014 Article 65 which is concerning Regional Government, regional head have some duties, such as (Indonesia, 2014):

- Leading the implementation of Government Affairs which are Region authority based on the provisions of the legislation and policies set with Regional People's Representative Assembly (DPRD).

- Maintaining community's peace and order.

- Arranging and submitting a local regulation (Perda) draft about RPJPD and RPJMD to be discussed together with Regional People's Representative Assembly (DPRD), as well as formulating and stipulating RKP

- Drafting and submitting a local regulation (Perda) draft concerning APBD, APBD's amendments, and the accountability of the APBD implementation to DPRD to be discussed together.

- Representing the region inside and outside the court and appointing a legal representative to represent in accordance with statutory provisions

- Propose the appointment of deputy regional head.

- $\quad$ Conduct other duties in accordance with statutory provisions.

In conducting this task, the regional head is assisted by the deputy regional head. According to

Law Number 23 of 2014 Article 66, the duties of the deputy regional head are (Indonesia, 2014):

- Assist regional head in:

- Lead the implementation of Government Affairs which are the Region authority.

- Coordinate Regional Apparatus's activities and follow up the reports and/or the findings from the supervisory apparatus's supervision.

- Monitor and evaluate the implementation of Regional Government which is conducted by the Provincial Regional Apparatus for the deputy governor.

- Monitor and evaluate implementation of Regional Government which is conducted by local aparatus of Regency/city, district, and/or Village for the deputy regent/ mayor.

- Providing advice and consideration to regional heads in the implementation of Regional Government.

- Conduct the duties and authority of the regional head if the regional head is serving a period of detention or temporarily unavailable. 
INTERNATIONAL JOURNAL OF ACADEMIC RESEARCH IN BUSINESS AND SOCIAL SCIENCES Vol. 10, No. 2, Feb, 2020, E-ISSN: 2222-6990 @ 2020 HRMARS

- Conduct other tasks in accordance with statutory provisions.

In addition, the deputy regional head conducts other governmental tasks and obligations granted by the regional head which is determined by regional head's decision.

Based on the above provisions, the existence of the deputy regional head actually has a positive side. It can back up the regional head's tasks, so that the tasks become lighter in conducting regional government. Especially in large areas, large populations, and in areas which have complex problems faced by local governments.

Another positive side is avoiding the leadership vacuum in the regional government operation because the deputy regional head can replace the regional head who is serving a period of detention or being temporarily unavailable. It is very useful because many regional heads are serving detention for being involved in corruption cases. Data shows that during 2004-2018, there were 100 regional heads in Indonesia caught Catch Hands Operation (OTT) by Corruption Eradication Commission (KPK). The regional heads caught by the KPK consisted of governors (15 people), regents (62 people), and mayors (23 people) (Rismawan, 2018).

On the other hand, the existence of the deputy regional head has negative side that is add the burden on the regional budget. However, this is not a serious problem. Another negative side of the existence of the deputy regional head is the lack of synergy and harmony between the regional head and the deputy regional head in leading the regional government. It is caused by many conflicts that arise between the regional head and his deputy and results in a split of partnership between them. The conflict usually occurs only a few months after the couple is appointed. As a result, for almost five years of his tenure, the regional government has not been effective.

One reason of conflicts between regional heads with their deputies is the coalition built by the supporting parties is a pragmatic coalition that is only to win the elections, not to advance the region. The coalition is forced by the supporting political parties even though the candidate pairs of regional head and deputy do not have the same vision and mission. Both of them have no chemistry at all from the beginning they met and work for office. The regional head and his deputy are like a pair of 'husband and wife' who are 'forced marriages' to fulfill the wishes of 'parents' (political party bearers). As a result, after they are 'married' (elected), they encounter many discrepancies and conflicts that lead to divorce (breaking up the partnership).

Other reason of conflicts is the position and role of the deputy regional head is not proportional compared with the regional head. In this case, deputy regional heads are often marginalized in positions and roles that are politically or financially unfavorable. Although Law Number 23 of 2014 has stipulated the duties of the deputy regional head but in practice the duties are still general in nature. Beside the Law Number 23 of 2014, the tasks of the deputy regional head are also stipulated in the regional head decree (Indonesia, 2014). However, as long as these tasks can be conducted by the regional head himself, these tasks will not be left to his representatives. It caused the presence of deputy regional head as only a complement and 'spare tire' because the dominant role in regional governance was conducted by the regional head.

In addition, the assignments given by regional heads to their representatives are tasks that are less strategic or lack financial benefits. It caused many deputy regional heads dissatisfied, so the relationship between the two of them was less harmonious and often led to conflicts and breaking up the partnership. 
INTERNATIONAL JOURNAL OF ACADEMIC RESEARCH IN BUSINESS AND SOCIAL SCIENCES Vol. 10, No. 2, Feb, 2020, E-ISSN: 2222-6990 @ 2020 HRMARS

Another cause is unhealthy political competition between the regional head and his deputy in the next election. Incumbent regional heads who will run in the next elections often assess deputy regional heads as a threat. It causes the regional head to limit the space for his representative by assigning his representative to tasks that are less strategic, so that the influence and popularity of his representative is not prominent in the public's eyes. If the deputy regional head is given strategic tasks, it is feared that his influence and popularity will be more prominent than that the regional head, so it is feared that his deputy will works for office and win in the next election.

This caused many regional heads broke up the partnership with their representatives. For example, during the 2005-2014 elections, there were 971 (94\%) regional heads who conflicted and broke up the partnership with their representatives. Only 77 pairs (6\%) of regional head and their deputies remained in harmony until the end of their tenure and advanced together in the next local elections (Ronald, 2018).

Conflicts and partnership broke out between the regional head and his deputy occurred in all regions of Indonesia. For example, the conflict between the Regent of Garut in West Java (Aceng H.M. Fikri) with his deputy (Dicky Candra) in 2011 (Herdiana, 2011). The conflict between the regional head and his deputy continued after 2014. Another example are the conflict between the Regent of Kuantan Singingi Regency in Riau (Sukarmis) and his representative (Zulkifli), in February 2016, between the Governor of North Kalimantan (IriantoLambrie) and his deputy (UdinHianggio) in October 2017, and the Regent Tolitoli (Mohammad Saleh Bantilan) with his deputy (Abdul Rahman H Buding) in the end of January 2018 (Nadlir, 2018).

To prevent a broken partnership between the regional head and the deputy regional head in Law Number 9 of 2015 concerning the Second Amendment to Law Number 23 of 2014 concerning Regional Government in Article 66 Paragraph (4), it is stated that the deputy regional head must conduct joint tasks with the regional head until the end of their tenure. However, this provision has been violated in practice because there are no strict legal sanctions (Indonesia, 2014; Indonesia, 2015).

The large number of conflicts between regional heads and their deputies raises a big question: is regional deputy heads needed in Indonesia?

Juridically, in the 1945 Constitution, the position of deputy regional head is unknown. It is different from the position of vice president which is mentioned in the constitution. The 1945 Constitution is a type of statutory regulation that occupies the highest hierarchy in Indonesia. Not mentioning the position of deputy regional head in the constitution shows that the position of deputy regional head is actually not as important as the position of vice president. The position of deputy regional head is only regulated in Law Number 23 of 2014 concerning Regional Government (Indonesia, 2014).

Empirically, many conflicts between the regional head and deputy regional head show the existence of the deputy regional head has more harm than benefits. Some cases in several regions show that the deputy regional head does not significantly interfere the operation of regional government. For example, in DKI Jakarta, Governor Anis Baswedan was abandoned by his deputy Sandiaga Uno because he was candidate for vice president. Likewise, in Cirebon, Mayor NasrudinAzis led without deputy mayor in the last two years of his tenure. During the new order, the non existence of deputy regional head did not interfere the operation of regional government. 
From the view of sociologically, the position of deputy regional head will accommodate the representation of people's aspirations. It is very important especially for areas where the majority of the population is Christian or Hindu. In this case, the regional head who is Christian or Hindu can be paired with the deputy regional head who is Muslim, so the pair represents the religion in the area. However, this casuistic and argument can be easily broken because even though it only elects Christian regional heads, it does not matter as long as the regional head acts fairly towards all religious adherents.

Meanwhile, from the political view, the presence of pair candidate of regional head and deputy regional head will broaden the representation of political power in the region. Political parties can form a coalition in carrying the candidate pairs of regional head and deputy regional head, so that the candidate pairs elected represent more political power in the region. However, this argument is loaded with the political interests of political parties to power by placing their cadres as regional heads or deputy regional heads.

From the public and regional government administration view, the existence of the deputy regional head has more harms than benefits. Actually, every region has no need for a deputy regional head.It is needed when it is situational namely if the area has a large area, has a large population, and holds very complex government affairs.

It is recommended that the deputy regional head is not selected in pair with the regional head in the election but is chosen by the regional head after the regional head is appointed. Thus, regional heads can choose people who has one vision and chemistry, so that the two of them will be harmonious in running the wheels of regional government.

It has actually been regulated in Law Number 23 of 2014 article 65 Paragraph (1) letter $f$ which is stated that one of the tasks of regional head is propose the appointment of deputy regional head. However, this task was later abolished through Law Number 9 of 2015 concerning the Second Amendment to Law Number 23 of 2014 concerning Regional Government. As a result, the deputy regional head is elected in a pair with the regional head in the election (Indonesia, 2014; Indonesia 2015).

The desire of some circles to maintain the existence of the deputy regional head elected in a pair with the regional head in the elections is laden with political interests. These political interests have sacrificed a much greater interest, namely the effectiveness of the regional government's operation. The Ministry of Home Affairs has planned to change the provisions regarding the deputy regional head since 2010. However, the plan failed in the middle of the road due to the strong political interests of political parties to power by placing its cadres as deputy regional heads throughout Indonesia.

\section{Conclusion and Implication}

Based on the description above, it can be concluded that:

- The positive side of the existence of deputy regional heads in Indonesia, namely:

- Back up the tasks of regional heads, so that the tasks of regional heads become lighter in conducting regional government.

- Avoid and anticipate leadership vacancies in the operation of regional government because the deputy regional head can replace the regional head who is serving a period of detention or being temporarily unavailable. 
INTERNATIONAL JOURNAL OF ACADEMIC RESEARCH IN BUSINESS AND SOCIAL SCIENCES Vol. 10, No. 2, Feb, 2020, E-ISSN: 2222-6990 @ 2020 HRMARS

While the negative sides are:

- The presence of the deputy regional head adds the burden on the regional budget.

- The presence of deputy regional heads has led to many conflicts with regional heads, thus disrupting the operation of regional government.

- The existence of the deputy regional head so far has more harms than benefits.

- Factors that cause conflicts between regional heads and deputy regional heads are:

- The coalition established between the regional head and the deputy regional head is a pragmatic coalition and often being forced.

- The position and role of the deputy regional head is not proportional with the regional head.

- Assignments given to deputy regional head are tasks that are less strategic or lack financial effects that are beneficial to the deputy regional head.

- There is political competition between the regional head and the deputy regional head in winning the next election.

- The needs of deputy regional head in Indonesia have to consider the area, population, complexity of regional government affairs, and the effectiveness of regional government operations. However, these considerations are often defeated by the political interests of political parties to power by placing their cadres as deputy regional heads.

This study provides theoretical implications about the position of deputy regional head in Indonesia despite the fact that they also have negative sides. However, for the practical implication, it is expected that the results of this study can be referred to as sources for policy making regarding the division of role between regional head and deputy of regional head.

\section{References}

Asshiddiqie, J. (2010). Perihal Undang-Undang. Jakarta: Rajawali Persada

Budiardjo, M. (2008). Dasar-dasar Ilmu Politik. Jakarta: PT. GramediaPustaka Utama

Creswell, J. W. (2014). Research Design. Pendekatan Kualitatif, Kuantitatif, dan Mixed. Yogyakarta: Pustaka Pelajar

Herdiana, I. (2011). Konflik Dialami Mayoritas Kepala Daerah \& Wakilnya. Accessed on January 2020, https://news.okezone.com/read/2011/09/07/340/500048/konflik-dialami-mayoritas-kepaladaerah-wakilnya

Indonesia. (2014). Undang-UndangNomor 23 Tahun 2014 tentangPemerintahan Daerah

Indonesia. (2015). Undang-UndangNomor 9 Tahun 2015 tentangPerubahanKeduaAtasUndangUndangNomor 23 Tahun 2014 tentangPemerintahan Daerah

Nadlir, I. (2018). Mendagri Ingatkan Kepala Daerah dan Wakilnya Tak Tunjukkan Konflik Secara Terbuka. Accessed on 2020, https://nasional.kompas.com/read/2018/02/05/20415641/mendagri-ingatkan-kepala-daerahdan-wakilnya-tak-tunjukkan-konflik-secara?page=all

Rismawan, I. (2018). Data ICW: 104 Kepala Daerah TerjeratKorupsi, Sebanyak 29 Orang di Tahun 2018. Accessed on January 2020, darihttp://www.tribunnews.com/section/2018/12/19/dataicw-104-kepala-daerah-terjerat-korupsi-sebanyak-29-orang-di-tahun-2018?page=2 
INTERNATIONAL JOURNAL OF ACADEMIC RESEARCH IN BUSINESS AND SOCIAL SCIENCES Vol. 10, No. 2, Feb, 2020, E-ISSN: 2222-6990 @ 2020 HRMARS

Ronald. (2018). Sejak Pilkada 2005-2014, 971 kepala daerah pecah kongsi dengan wakilnya. Accessed on January 2020, https://www.merdeka.com/politik/sejak-pilkada-2005-2014-971-kepaladaerah-pecah-kongsi-dengan-wakilnya.html

Wahid, A. B. (2018). Eks Dirjen Kemendagri: 971 Kepala Daerah Pecah Kongsi Selama 2005-2014. Accessed on January 2020, https://news.detik.com/berita/d-3860004/eks-dirjen-kemendagri971-kepala-daerah-pecah-kongsi-selama-2005-2014 